\title{
African Americans in the US Women's National Basketball Association, 2006: From the NCAA to the WNBA
}

\author{
Amadu Jacky Kaba \\ Department of Sociology, Anthropology and Social Work, Seton Hall University, South Orange, USA \\ Email: Amadu.Kaba@shu.edu
}

Received September $17^{\text {th }}, 2011$; revised October $25^{\text {th }}, 2011$; accepted December $6^{\text {th }}, 2011$

\begin{abstract}
This research study presents a social science examination of the US Women's National Basketball Association (WNBA) players for the 2006 season. This study does not examine on-court performance data. Instead, it focuses on the profile of the players as human beings, by looking at their race, average age, height and weight, colleges or universities attended in the United States and which regions these institutions are located in, demographics of international players, graduation rates, etcetera. The paper also examines the issue of gender bias when it comes to salaries and advertisement or endorsement opportunities.
\end{abstract}

Keywords: Women's National Basketball: USA; African American Women; Educational Attainment; NCAA; Gender and Sports

\section{Introduction}

African American females, like their male counterparts have been playing or participating in organized sports in the United States from the 1800s or before. Among the sports that African American females have been participating in are: Basketball, Fencing, Field Hockey, Figure Skating, Golf, Gymnastics, Lacrosse, Rowing, Softball, Soccer, Swimming, Tennis, Track and Field, and Volleyball. Due to its popularity in the United States and the world, and also due to their history in the country, the relationship between African American females and Basketball has been unique. That is because it is the sport that has contributed to providing college scholarships to a very large number of Black females in the past several decades. By the 21st Century, basketball is also providing African American women with jobs and advertisement opportunities, although not as large as their male counterparts (Abney, 1999; Baker, 2008; Grundy \& Shackelford, 2006; McDonald, 2000; Ruihley, 2010; Spencer \& McClung, 2001; Staffo, 1998a; Wearden \& Creedon, 2002; Yafie, 1997). As Abney (1999) notes: “African American women have made significant contributions and set standards of excellence in every aspect of sport. Although seldom recognized and rewarded, they have excelled in many sports including tennis, golf, gymnastics, figure skating, volleyball, lacrosse, field hockey, fencing, rowing, track, and basketball. African American women have attained prominence and had successful careers as Olympians, professional and collegiate athletes, coaches, administrators, officials, athletic trainers, and sportscasters... African American women have had to overcome many odds, including the double jeopardy of gender and race. During the early 1900s, they competed during times when women were not encouraged to become athletes and African Americans were not given equal opportunities” (p. 35).

The United States women's professional basketball league, the Women's National Basketball Association (WNBA) is increasing its popularity not only in the US, but all over the world, despite the fact that the league as of 2011 has been in existence for only 15 years. Picker (2006) quoted the league's former president, Donna Orender as saying that: "Not only is basketball the No. 1 participatory sport for girls in the United States, there are 100 million females playing this sport around the world... It is a global game for women as well as for men” (p. D6). Staffo (1998a) also points out that 80 million females across the world play basketball and that in the United States it was the sport most female youths play (p. 191).

The purpose of this study is to take an in-depth social science examination of the players that comprised the United States Women's National Basketball Association (WNBA) for the 2006 season. The study does not include statistics showing the numbers or percentages of points, assists, rebounds, etcetera of the players (Gomez et al., 2009; Kochman \& Goodin, 2003). Nor does this paper include the teams that each player is on Instead, this study focuses only on the profile of these players or in knowing their various characteristics such as their racial breakdown, colleges and universities attended, international players, their average height, weight, and age. In some instances, comparisons will be made with their male counterparts in the 2005-2006 US National Basketball Association (NBA). The paper begins with the methodology. Next it presents the statistical findings of the various characteristics of the players. Finally, the paper presents a discussion section with analysis of some of the data in the findings.

\section{Methodology}

All of the data were compiled from the official website of the WNBA (http://www.wnba.com) as of May 20, 2006, the official opening day of the 2006 season. The WNBA presents a profile of each of its players in alphabetical order. I printed out the profile of each player and transferred her data into an excel spreadsheet in alphabetical order. One large table was created and it contains the profiles of all the players. The variables include date of birth and age, racial background, height, weight, position played, college/university or institution attended, state in the US where institution is located, region of the country (e.g. Northeast, Midwest, South and 
West, using US Census or government classification) where institution is located, and year of graduation for those players who attended colleges or universities in the United States. Data for salaries of WNBA players are not posted on the league's website nor are they posted by the USA Today newspaper, which posts salary figures for the National Basketball Association (NBA), their male counterparts. However, according to Isaacson (2006): “The WNBA rookie minimum is $\$ 31,800$, as opposed to nearly $\$ 400,000$ in the NBA. The average WNBA salary is $\$ 50,000$, as opposed to the NBA's $\$ 4.5$ million” (p. 1; also see Staffo, 1998; Cahppell \& Karageorghis, 2001). As little as their salaries are by 2006, those figures actually increased from the 1990s. For example, according to Staffo (1998a): “...WNBA salaries range from $\$ 15,000$ to $\$ 50,000$ excluding meal and travel money... another source described the same sliding scale but listed the minimum at only $\$ 10,000 ”$ (p. 193). Kaba (2011a) points out that the average salary of US National Basketball Association (NBA) players for the 2005-2006 season was \$3.9 million (p. 7).

Data for WNBA players who are foreign-born were also compiled and computed. The figures for age are as of May 31, 2006. The players are also separated into two categories based on their pictures posted on the WNBA official website: 1) Players of African decent (but referred to as Black players in this study); and 2) White players. This author, who has published extensively on the racial make-up of not only the people of the United States, but also the world, utilized the classification of various racial groups in the US to divide the players (see Kaba, 2006ab, 2011a). For example, in the US, people who are of Turkish, Arab, Jewish, Iranian, or European ancestry, are classified as White, while anyone with Black African ancestry is classified as Black or African American. And individuals from East Asia and South Asia are classified under Asian/Pacific Islanders.

It is useful to note that these classifications are by no means saying that is what these players are or identified themselves as. The classifications are utilized only to help us understand the racial make-up of the league.

\section{General Findings}

\section{Numbers, Percentages and Racial Make-Up of WNBA Players}

Like their male counterparts in the NBA, players of African descent or Black players comprise the majority in the US Women's National Basketball Association (WNBA). However, their proportion is not as high as the men. Of a list of 177 names of WNBA players on the league's website as of 12:30 pm on May 20, 2006 (opening day of the 2006 regular season), data were not available for two players, bringing the list down to 175 players. The data in this entire section focus on these 175 players, all of whom are either categorized as Black or White (No other players from other racial groups are among those 175 total players). Of those 175 players, Black players comprised 118 (67.4\%), and White players comprised 57 (32.6\%) (Table 1). Lapchick and Kushner (2006) present a breakdown of WNBA players for the 1999 and 2005 seasons, utilizing cultural, instead of racial definition. They claim that in the 1999 WNBA season, African American players comprised $64 \%$, White players, 32\% and Latina players, 2\%. For the
Table 1.

Profile of 2006 WNBA players: As of May 20, 2006.

\begin{tabular}{ccccc}
\hline Total $^{\#}$ of all Players & \# of Black Players & \% & \# of White Players & \% \\
\hline 175 & 118 & 67.4 & 57 & 32.6 \\
\hline
\end{tabular}

Source: Compiled and computed based on data on the WNBA website. www. wnba.com, 2006.

2005 WNBA season, African American players comprised 130 (63\%); White players, 69 (34\%); Latina players, 2 (1\%); 1 Asian player; and a group of players called "Other”, 3 (1\%) (p. 13). For comparative purposes, of the 430 players in the NBA during the 2005-2005 season, 327 (76\%) were Black, 101 (23.5\%) were White, and 2 were Northeast Asians (Kaba, 2011a: p. 4).

\section{Average Age of All Players}

On average, Black players are older than White players. The average age of all 175 players was 25.9 years. The average age of the Black players was 26.2 years, and the average age of the White players was 25.3 years (Table 2). In the NBA, during the 2005-2006 season, the average age of all 430 players was 26.5 years; 26.7 years for Blacks and 26.1 years for White players (Kaba, 2011a: p. 12).

In addition, no player in the WNBA was 20 years or younger. A total of 96 players (54.9\% of all players) were 21 - 25 years old. Of that total, Black players accounted for 61 (63.5\%, but $51.7 \%$ of all 118 Black players, and $34.9 \%$ of all 175 players), and White players accounted for 35 (36.5\%, but $61.4 \%$ of all 57 White players, and $20 \%$ of all 175 players). A total of 41 players (23.4\% of all players) were 26 to 29 years old. Of that total, Black players comprised 28 (68.3\%, but 23.7\% of all Black players, and $16 \%$ of all 175 players), and White players comprised 13 (31.7\%, but $22.8 \%$ of all White players, and $7.4 \%$ of all 175 players). A total of 37 players (21.1\% of all players) were 30 years or older. Of that total, Black players comprised 28 (75.7\%, but $23.7 \%$ of all Black players, and $16 \%$ of all 175 players), and White players comprised 9 (24.3\%, but $15.8 \%$ of all White players, and 5.1\% of all 175 players) (Table 3).

\section{Average Height of All Players}

Players of African descent in the WNBA are shorter on average than White players. The average height of all WNBA players was 72.4 inches (over 6'0"). The average height of Black players was 72.3 inches (over 6'0"), and the average height of White players was 72.6 inches (upwards to 6’1”) (Table 4). In the NBA, during the 2005-2006 season, the average height of all players was 79.2 inches (just over 6'7”); 78.6 inches (up to 6'7”) for Black players; and 81 inches (6’9”) for White players (Kaba, 2011a: p. 6).

Table 2.

Average age of WNBA players.

\begin{tabular}{ccc}
\hline All Players $(\mathbf{N}=\mathbf{1 7 5})$ & Black Players $(\mathbf{N}=\mathbf{1 1 8})$ & White Players $(\mathbf{N}=\mathbf{5 7})$ \\
\hline Average Age & Average Age & Average Age \\
25.9 (years) & 26.2 (years) & 25.3 (years) \\
\hline
\end{tabular}

Source: Compiled and computed based on data on the WNBA website. www. wnba.com, 2006. 
Table 3.

Age groups of WNBA players: 2006 season.

\begin{tabular}{|c|c|c|c|c|}
\hline & & & $\%$ of all & $\%$ of all \\
\hline Item & Number & \% of total (175) & Blacks & Whites \\
\hline \# of All Players 20 Years Old or Younger & 0 & 0 & 0 & 0 \\
\hline \# of All Players 21 - 25 Years Old & 96 & 54.9 & & \\
\hline \# of All Black Players 21 - 25 Years Old & 61 & 34.9 & 51.7 & \\
\hline \# of All White Players 21 - 25 Years Old & 35 & 20 & & 61.4 \\
\hline \# of All Players 26 - 29 Years Old & 41 & 23.4 & & \\
\hline \# of All Black Players 26 - 29 Years Old & 28 & 16 & 23.7 & \\
\hline \# of All White Players 26 - 29 Years Old & 13 & 7.4 & & 22.8 \\
\hline \# of All Players 30 Years Old or Older & 37 & 21.1 & & \\
\hline \# of All Black Players 30 Years Old or Older & 28 & 16 & 23.7 & \\
\hline \# of All White Players 30 Years Old or Older & 9 & 5.1 & & 15.8 \\
\hline
\end{tabular}

Source: Compiled and computed based on data on the WNBA website. www.wnba.com, 2006.

Table 4.

Average height of WNBA players.

\begin{tabular}{ccc}
\hline All Players $(\mathbf{N}=\mathbf{1 7 5})$ & Black Players $\mathbf{N}=118$ & White Players $\mathbf{N}=\mathbf{5 7}$ \\
\hline Average Height & Average Height & Average Height \\
72.4 inches (over 6’0”) & 72.3 inches (over 6'0”) & 72.6 inches (6’1”) \\
\hline
\end{tabular}

Source: Compiled and Computed based on Data on the WNBA Website. www. wnba.com, 2006.

It is useful to note that the mean or average height of females 20 years and over in the US from 1999 to 2002 was 63.8 inches or almost 5'4" tall. When broken down according to race/cultural background both non-Hispanic Whites and non-Hispanic Blacks are taller than the national average (64.2 inches each for those 20 years and over) and they are also both at 64.6 inches tall each for those 20 - 39 years (Table 5). For males 20 years and over in the US during that same period, their average height was 69.2 inches; 69.7 inches for non-Hispanic White males; and 69.5 inches for non-Hispanic Black males (Kaba, 2011a: p. 10).

In addition to their average height, a total of 107 players (61.1\% of all players) are 6'0" or taller. Of that total, 74 Black players (42.3\% of all players, but $62.7 \%$ of all Black players) are 6 ' 0 " or taller, and 33 White players $(18.9 \%$ of all players, but $57.9 \%$ of all White players) are 6'0" or taller. A total of 57 players (32.6\% of all players) are 6' 1 ' to 6'2' tall. Of that total, 42 Black players (24\% of all players, but $35.6 \%$ of all Black

Table 5.

Mean height (inches) for females 20 years and above, 1999-2002: United States.

\begin{tabular}{ll}
\hline Females & \\
\hline 20 Years \& Over & 63.8 \\
\hline Non-Hispanic Black Females & 64.2 \\
\hline 20 Years \& Over & 64.6 \\
20 - 39 Years & \\
\hline Non-Hispanic White Females & 64.2 \\
\hline 20 Years \& Over & 64.6 \\
\hline
\end{tabular}

Source: Ogden et al., 2004, pp. 8-15. players) are 6'1' to 6'2” tall, and 15 White players (8.6\% of all players, but $26.3 \%$ of all White players) are 6' 1 " to 6'2" tall. A total of 68 players (38.9\% of all players) are from 5'3” to 5’11” tall.

A total of 50 players (28.6\% of all players) are 6'3” or taller. Of that total, 32 Black players (18.3\% of all players, but $27.1 \%$ of all Black players) are 6'3” or taller, and 18 White players ( $10.3 \%$ of all players, but $31.6 \%$ of all White players) are 6 ' 3 ”' or taller. A total of 30 players (17.1\% of all players) are 6' 4 " or taller. Of that total, 17 Black players (9.7\% of all players, but $14.4 \%$ of all Black players) are 6 ' 4 ” or taller, and 13 White players (7.4\% of all players, but $22.8 \%$ of all White players) are 6' 4 " or taller. A total of 16 players (9.1\% of all players) are 6 '5" or taller. Of that total, 6 Black players (3.4\% of all players, but $5.1 \%$ of all Black players) are 6'5" or taller, and 10 White players (5.7\% of all players, but $17.5 \%$ of all White players) are 6 '5” or taller. Finally, a total of 5 players (2.9\% of all players) are 6 ' 6 " or taller. Of that total, 1 Black player $(0.6 \%$ of all players, but $0.8 \%$ of all Black players) is 6' 6 " or taller, and 4 White players (2.3\% of all players, but $7 \%$ of all White players) are 6'6" or taller. Four White players (2.3\% of all players, $7 \%$ of all White players) are 6'7' or taller. Three White players are 6'8" or taller. There are 2 White players who are 6'8" tall, and 1 White player who is 7'2" tall (Table 6).

\section{Average Weight of All Players}

There might be a correlation between being taller and also weighing heavier. White players in the WNBA on average are heavier than Black players. The average weight of all WNBA players was 168.7 pounds. The average weight of White players was 169.7 pounds, and 168.1 pounds for Black players (Table 7). In the NBA, during the 2005-2006 season, the average weight of all 430 players was 223.9 pounds; 220.3 pounds for Blacks; and 233.6 pounds for Whites (Kaba, 2011a: p. 10).

In the general US population, from 1999 to 2002 the mean or average weight of females 20 years and over was 162.9 pounds. For non-Hispanic White females, it was 161.7 pounds, and 182.4 pounds for non-Hispanic Black females during that same period. For those aged 20 - 39 years, it was 158.4 pounds for non-Hispanic White females, and 179.2 pounds for non-Hispanic Black females (Table 8). For males 20 years and over in the US during that same period, their average weight was 
Table 6.

Height breakdown of WNBA players.

\begin{tabular}{|c|c|c|c|c|}
\hline & & $\%$ of all & \% of Black & \% of White \\
\hline Item & $\#$ & players & Players only & Players only \\
\hline Total $^{\#}$ of all players 6 ' 0 " and taller & 107 & 61.1 & & \\
\hline Total $^{\#}$ of all Black players 6 ' $0^{\prime}$ and taller & 74 & 42.3 & 62.7 & \\
\hline Total $^{\#}$ of all White players $6{ }^{\prime} 0^{\prime \prime}$ and taller & 33 & 18.9 & & 57.9 \\
\hline Total $^{\#}$ of all players 6' 1 " to 6'2" tall & 57 & 32.6 & & \\
\hline Total $^{\#}$ of all Black players 6' 1 " to 6'2" tall & 42 & 24 & 35.6 & \\
\hline Total" of all White players 6'1" to 6'2" tall & 15 & 8.6 & & 26.3 \\
\hline Total" of all players 6' 3 " and taller & 50 & 28.6 & & \\
\hline Total $^{\#}$ of all Black players 6'3" and taller & 32 & 18.3 & 27.1 & \\
\hline Total $^{\#}$ of all White players 6'3" and taller & 18 & 10.3 & & 31.6 \\
\hline Total ${ }^{\#}$ of all players 6 ' 4 " and taller & 30 & 17.1 & & \\
\hline Total $^{\#}$ of all Black players 6' ${ }^{\prime}$ " and taller & 17 & 9.7 & 14.4 & \\
\hline Total $^{\#}$ of all White players $6{ }^{\prime} 4^{\prime \prime}$ and taller & 13 & 7.4 & & 22.8 \\
\hline Total ${ }^{\#}$ of all players 6'5" and taller & 16 & 9.1 & & \\
\hline Total $^{\#}$ of all Black players 6'5" and taller & 6 & 3.4 & 5.1 & \\
\hline Total $^{\#}$ of all White players $6{ }^{\prime}{ }^{\prime}$ " and taller & 10 & 5.7 & & 17.5 \\
\hline Total ${ }^{\#}$ of all players 6 ' 6 " and taller & 5 & 2.9 & & \\
\hline Total $^{\#}$ of all Black players 6'6" and taller & 1 & 0.6 & 0.8 & \\
\hline Total $^{\#}$ of all White players $6{ }^{\prime} 6^{\prime \prime}$ and taller & 4 & 2.3 & & 7 \\
\hline Total $^{\#}$ of all players 5'3” to 5 ' 11 ” tall & 68 & 38.9 & & \\
\hline
\end{tabular}

Source: Compiled and computed based on data on the WNBA website. www.wnba.com, 2006.

Table 7.

Average weight of WNBA players.

\begin{tabular}{ccc}
\hline All Players $(\mathbf{N}=\mathbf{1 7 0})$ & Black Players $(\mathbf{N}=114)$ & White Players $(\mathbf{N}=\mathbf{5 6})$ \\
\hline $\begin{array}{c}\text { Average Weight } \\
\text { (pounds) }\end{array}$ & $\begin{array}{c}\text { Average Weight } \\
\text { (pounds) }\end{array}$ & $\begin{array}{c}\text { Average Weight } \\
\text { (pounds) }\end{array}$ \\
168.7 & 168.1 & 169.7 \\
\hline
\end{tabular}

Source: Compiled and computed based on data on the WNBA website. www. wnba.com, 2006.

Table 8.

Mean weight (pounds) for females 20 years and above, 1999-2002: United States.

\begin{tabular}{ll}
\hline Females & \\
\hline 20 Years \& Over & 162.9 \\
\hline Non-Hispanic Black Females & 182.4 \\
\hline 20 Years \& Over & 179.2 \\
20 - 39 Years & \\
\hline Non-Hispanic White Females & 161.7 \\
\hline 20 Years \& Over & 158.4 \\
\hline
\end{tabular}

Source: Ogden et al., 2004, pp. 8-15.

189.8 pounds; 193.1 pounds for non-Hispanic White males; and 189.2 pounds for non-Hispanic Black males (Kaba, 2011a: p. 11).

\section{Number of Players Institutions in Sending States Had in the WNBA: 2006 Season}

A total of 33 states (with Washington DC as a state equiva- lent) in the country had colleges and universities with a combined total of 156 players (89.13\% of all 175 players) on the rosters of WNBA teams on opening day on May 20, 2006. Of those 156 players, Blacks comprised 114 (73.1\%), and Whites comprised 44 (26.9\%).

A total of 6 states had double figure numbers of players on opening day: Tennessee, 14 players (13 Blacks and 1 White); Texas, 11 players (10 Blacks and 1 White); Connecticut, 12 players (7 Blacks and 5 Whites); Louisiana, 12 players (all 12 are Black players); California, 11 players (9 Blacks and 2 Whites); and Florida, 11 players (9 Blacks and 2 Whites).

Two states had 9 players each: Georgia (7 Blacks and 2 Whites); and North Carolina (8 Blacks and 1 White). The state of Virginia had 6 players (4 Blacks and 2 Whites). Three states had 5 players each: Kansas (1 Black and 4 Whites); Indiana (2 Blacks and 3 Whites); and Pennsylvania (4 Blacks and 1 White). Four states had 4 players each: Alabama (all 4 are Black players); Iowa (3 Blacks and 1 White); and Utah (1 Black and 3 Whites). Three states had 3 players each: Michigan (all 3 are White players); Missouri (all 3 are Black players); and New Jersey (all 3 are Black players).

A total of 6 states had 2 players each: Massachusetts (1 Black and 1 White); Minnesota (all 2 are White players); Mississippi (all 2 are Black players); Ohio (1 Black and 1 White); Oklahoma (1 Black and 1 White); Oregon (1 Black and 1 White); and South Carolina (all 2 are Black players). A total of 7 states had 1 player each: Arkansas (Black player); Colorado (White player); Nebraska (White player); Nevada (White player); Washington DC (Black player); West Virginia (White player); and Wisconsin (Black player) (Table 9).

\section{Sending Institutions (Colleges and Universities)}

A total of 69 colleges and universities in the United States 
Table 9.

Number of players institutions (colleges or universities may send 1 or more players) in sending states sent: 2006 WNBA season.

\begin{tabular}{|c|c|c|c|}
\hline $\mathrm{N}=156$ & & & \\
\hline State & $\begin{array}{c}\text { Total }{ }^{\#} \text { of } \\
\text { Players Sent }\end{array}$ & $\begin{array}{c}\text { \# of Black } \\
\text { Players }\end{array}$ & $\begin{array}{l}\text { \# of White } \\
\text { Players }\end{array}$ \\
\hline Tennessee & 14 & 13 & 1 \\
\hline Texas & 11 & 10 & 1 \\
\hline Connecticut & 12 & 7 & 5 \\
\hline Louisiana & 12 & 12 & 0 \\
\hline California & 11 & 9 & 2 \\
\hline Florida & 11 & 9 & 2 \\
\hline Georgia & 9 & 7 & 2 \\
\hline North Carolina & 9 & 8 & 1 \\
\hline Virginia & 6 & 4 & 2 \\
\hline Kansas & 5 & 1 & 4 \\
\hline Indiana & 5 & 2 & 3 \\
\hline Pennsylvania & 5 & 4 & 1 \\
\hline Illinois & 4 & 3 & 1 \\
\hline Alabama & 4 & 4 & 0 \\
\hline Iowa & 4 & 3 & 1 \\
\hline Utah & 4 & 1 & 3 \\
\hline Michigan & 3 & 0 & 3 \\
\hline Missouri & 3 & 3 & 0 \\
\hline New Jersey & 3 & 3 & 0 \\
\hline Massachusetts & 2 & 1 & 1 \\
\hline Minnesota & 2 & 0 & 2 \\
\hline Mississippi & 2 & 2 & 0 \\
\hline Ohio & 2 & 1 & 1 \\
\hline Oklahoma & 2 & 1 & 1 \\
\hline Oregon & 2 & 1 & 1 \\
\hline South Carolina & 2 & 2 & 0 \\
\hline Arkansas & 1 & 1 & 0 \\
\hline Colorado & 1 & 0 & 1 \\
\hline Nebraska & 1 & 0 & 1 \\
\hline Nevada & 1 & 0 & 1 \\
\hline Washington DC & 1 & 1 & 0 \\
\hline West Virginia & 1 & 0 & 1 \\
\hline Wisconsin & 1 & 1 & 0 \\
\hline Total & 156 & 114 & 42 \\
\hline
\end{tabular}

Source: Compiled and computed based on data on the WNBA website. www. wnba.com, 2006.

had a total of 156 players (89.1\% of all 175 players) in the WNBA on opening day, on May 20, 2006. Two Universities had double figure number of players: University of Connecticut, 12 (7 Blacks and 5 Whites), and the University of Tennessee, 11 (10 Blacks and 1 White). The University of Georgia had 8 players (6 Blacks and 2 Whites). Louisiana State University and Louisiana Tech University each had 5 players (all of them are Black). Four institutions had 4 players each: Duke University (3 Blacks and 1 White); Kansas State University (all 4 players are White); University of Florida (all 4 players are Black); and
University of Southern California (all 4 players are Black).

A total of 9 institutions (13\% of all 69 institutions) had 3 players each: Michigan State University (all 3 players are White); Penn State University (2 Blacks and 1 White); Rutgers University (all 3 players are Black); Texas Tech (all 3 players are Black); University of Iowa (all 3 players are Black); University of Missouri, Columbia (all 3 players are Black); University of North Carolina (all 3 players are Black); University of Notre Dame (1 Black and 2 Whites); and the University of Virginia (all 3 players are Black).

A total of 21 institutions (30.4\% of all 69 institutions) had 2 players each: Auburn University (all 2 players are Black); Baylor University (all 2 players are Black); Brigham Young University (1 Black and 1 White); DePaul University (all 2 players are Black); Florida International University (1 Black and 1 White); Florida State University (1 Black and 1 White); Mississippi State University (all 2 players are Black); North Carolina State University ( all two players are Black); Old Dominion University (1 Black and 1 White); Purdue University (1 Black and 1 White); Stanford University (all 2 players are Black); Tulane University (all 2 players are Black); University of California, Los Angeles (all 2 players are Black); University of Houston (all 2 players are Black); University of Kansas (all 2 players are Black); University of Minnesota (all 2 players are White); University of Oregon (1 Black and 1 White); University of South Carolina, Columbia (all 2 players are Black); University of Texas, Austin (1 Black and 1 White); University of Utah (all 2 players are White); and Vanderbilt University (all 2 players are Black).

A total of 30 institutions (43.5\% of all 69 institutions) had 1 player each: Boston College (Black player); Colorado State University (White player). Florida Atlantic University (Black player); Georgetown University (Black player); Georgia Tech (Black player); Harvard University (Black player); Iowa State University (White player); Liberty University (White player); The Master's College (White player); Ohio State University (White player); Pepperdine University (Black player); Saint Edwards University (Black player); Southeastern Oklahoma State University (Black player); Temple University (Black player); Texas Christian University (Black player); University of Alabama, Birmingham (Black player); University of Alabama, Tuscaloosa (Black player); University of Arkansas, Fayetteville (Black player); University of California, Santa Barbara (White player); University of Central Florida (Black player); University of Cincinnati (Black player); University of Illinois, Champaign (Black player); University of Memphis (Black player); University of Miami (Black player); University of Nebraska, Lincoln (White player); University of Nevada, Las Vegas (White player); University of Oklahoma (White player); University of Wisconsin (Black player); Western Illinois University (White player); and West Virginia University (White player) (Table 10).

\section{Number of Players Institutions and Regions Had in the WNBA: 2006 Season}

Institutions in the Southern United States sent the highest proportion of players to the WNBA. In fact, the South had the majority of players in the WNBA, compared to the other three official regions of the United States. Of 156 players for whom available data showed that they attended colleges or universities in the US, 85 (54.5\%) are from institutions located in the 


\section{A. J. KABA}

Table 10.

All 69 sending institutions and NCAA \& NAIA conferences: 2006 WNBA season.

\begin{tabular}{|c|c|c|c|c|}
\hline \multirow{2}{*}{$\mathrm{N}=156$ Players } & \multirow[b]{2}{*}{$\begin{array}{l}\text { Total }{ }^{\#} \text { of } \\
\text { Players }\end{array}$} & \multirow[b]{2}{*}{$\begin{array}{l}\text { \#of Black } \\
\text { Players }\end{array}$} & \multirow[b]{2}{*}{$\begin{array}{l}\text { \# of White } \\
\text { Players }\end{array}$} & \multirow[b]{2}{*}{ NCAA or NAIA Conference } \\
\hline & & & & \\
\hline University of Connecticut & 12 & 7 & 5 & Big East Conference \\
\hline University of Tennessee, Knoxville & 11 & 10 & 1 & Southeastern Conference \\
\hline University of Georgia & 8 & 6 & 2 & Southeastern Conference \\
\hline Louisiana State University & 5 & 5 & 0 & Southeastern Conference \\
\hline Louisiana Tech University & 5 & 5 & 0 & Western Athletic Conference \\
\hline Duke University & 4 & 3 & 1 & Atlantic Coast Conference \\
\hline Kansas State University & 4 & 0 & 4 & Big 12 Conference \\
\hline University of Florida & 4 & 4 & 0 & Southeastern Conference \\
\hline University of Southern California & 4 & 4 & 0 & Pacific-10 Conference \\
\hline Michigan State University & 3 & 0 & 3 & Big Ten Conference \\
\hline Penn State University & 3 & 2 & 1 & Big Ten Conference \\
\hline Rutgers University & 3 & 3 & 0 & Big East Conference \\
\hline Texas Tech University & 3 & 3 & 0 & Big 12 Conference \\
\hline University of Iowa & 3 & 3 & 0 & Big Ten Conference \\
\hline University of Missouri, Columbia & 3 & 3 & 0 & Big 12 Conference \\
\hline University of North Carolina, Chapel Hill & 3 & 3 & 0 & Atlantic Coast Conference \\
\hline University of Notre Dame & 3 & 1 & 2 & Big East Conference \\
\hline University of Virginia & 3 & 3 & 0 & Atlantic Coast Conference \\
\hline Auburn University & 2 & 2 & 0 & Southeastern Conference \\
\hline Baylor University & 2 & 2 & 0 & Big 12 Conference \\
\hline Brigham Young University & 2 & 1 & 1 & Mountain West Conference \\
\hline DePaul University & 2 & 2 & 0 & Big East Conference \\
\hline Florida International University & 2 & 1 & 1 & Sun Belt Conference \\
\hline Florida State University & 2 & 1 & 1 & Atlantic Coast Conference \\
\hline Mississippi State University & 2 & 2 & 0 & Southeastern Conference \\
\hline North Carolina State University & 2 & 2 & 0 & Atlantic Coast Conference \\
\hline Old Dominion University & 2 & 1 & 1 & Colonial Athletic Association \\
\hline Purdue University & 2 & 1 & 1 & Big Ten Conference \\
\hline Stanford University & 2 & 2 & 0 & Pacific-10 Conference \\
\hline Tulane University & 2 & 2 & 0 & Conference USA \\
\hline University of California, Los Angeles & 2 & 2 & 0 & Pacific-10 Conference \\
\hline University of Houston & 2 & 2 & 0 & Conference USA \\
\hline University of Kansas & 2 & 2 & 0 & Big 12 Conference \\
\hline University of Minnesota & 2 & 0 & 2 & Big Ten Conference \\
\hline University of Oregon & 2 & 1 & 1 & Pacific-10 Conference \\
\hline University of South Carolina, Columbia & 2 & 2 & 0 & Southeastern Conference \\
\hline University of Texas, Austin & 2 & 1 & 1 & Big 12 Conference \\
\hline University of Utah & 2 & 0 & 2 & Mountain West Conference \\
\hline Vanderbilt University & 2 & 2 & 0 & Southeastern Conference \\
\hline Boston College & 1 & 0 & 1 & Atlantic Coast Conference \\
\hline Colorado State University & 1 & 0 & 1 & Mountain West Conference \\
\hline Florida Atlantic University & 1 & 1 & 0 & Atlantic Sun Conference \\
\hline Georgetown University & 1 & 1 & 0 & Big East Conference \\
\hline Georgia Tech & 1 & 1 & 0 & Atlantic Coast Conference \\
\hline Harvard University & 1 & 1 & 0 & Ivy League \\
\hline Iowa State University & 1 & 0 & 1 & Big 12 Conference \\
\hline Liberty University & 1 & 0 & 1 & Big South Conference \\
\hline The Master's College & 1 & 0 & 1 & Golden State Athletic Conference (NAIA) \\
\hline Ohio State University & 1 & 0 & 1 & Big Ten Conference \\
\hline Pepperdine University & 1 & 1 & 0 & West Coast Conference \\
\hline Saint Edwards University & 1 & 1 & 0 & Heartland Conference (Division II) \\
\hline S.E. Oklahoma State University & 1 & 1 & 0 & Lone Star Conference (Division II) \\
\hline Temple University & 1 & 1 & 0 & Atlantic 10 Conference \\
\hline Texas Christian University & 1 & 1 & 0 & Mountain West Conference \\
\hline University of Alabama, Birmingham & 1 & 1 & 0 & Conference USA \\
\hline University of Alabama, Tuscaloosa & 1 & 1 & 0 & Southeastern Conference \\
\hline University of Arkansas, Fayetteville & 1 & 1 & 0 & Southeastern Conference \\
\hline University of California, Santa Barbara & 1 & 0 & 1 & Big West Conference \\
\hline University of Central Florida & 1 & 1 & 0 & Conference USA \\
\hline University of Cincinnati & 1 & 1 & 0 & Big East Conference \\
\hline University of Illinois, Champaign & 1 & 1 & 0 & Big Ten Conference \\
\hline University of Memphis & 1 & 1 & 0 & Conference USA \\
\hline University of Miami & 1 & 1 & 0 & Atlantic Coast Conference \\
\hline University of Nebraska, Lincoln & 1 & 0 & 1 & Big 12 Conference \\
\hline University of Nevada, Las Vegas & 1 & 0 & 1 & Mountain West Conference \\
\hline University of Oklahoma & 1 & 0 & 1 & Big 12 Conference \\
\hline University of Wisconsin & 1 & 1 & 0 & Big Ten Conference \\
\hline Western Illinois University & 1 & 0 & 1 & Mid Continent Conference \\
\hline West Virginia University & 1 & 0 & 1 & Big East Conference \\
\hline
\end{tabular}




\begin{tabular}{cccc}
\hline \multicolumn{1}{c}{ Total } & 156 & 114 & 42 \\
Percentages & & 73.1 & 26.9 \\
NAIA = National Association of Intercollegiate Athletics & & & \\
NCAA = National Collegiate Athletic Association & & & \\
\hline
\end{tabular}

Source: Compiled and computed based on data on the WNBA website. www.wnba.com, 2006.

South; 31 players (19.9\%) are from the Midwest; 21 players (13.4\%) are from the Northeast; and 19 players (12.2\%) are from the West. Of the 114 Black players who attended institutions in the US, 74 (64.9\%) are from the South; 15 players (13.2\%) are from the Midwest; 14 players (12.3\%) are from the Northeast; and 11 players (9.6\%) are from the West. of the 42 White players who data showed that they attended institutions in the US, 16 (38.1\%) are from the Midwest; 11 players (26.2\%) are from the South; 8 players (19\%) are from West; and 7 players $(16.7 \%)$ are from the Northeast. The 74 Black players who attended institutions in the South account for $47.4 \%$ of all 156 players who attended institutions in the US, and $42.3 \%$ of the total 175 players in the WNBA (Table 11).

\section{College or University Graduation Rates of WNBA Players: 2006 Season}

WNBA players may be among the top (if not the top) of professional teams in the United States with an extremely high proportion of their players with at least a bachelor's degree. These degrees are earned from many of the most highly ranked academic institutions in the country (such as Harvard University, Duke University, Stanford University, etcetera). To present a better perspective on the academic progress of WNBA players, this author compiled the names of the 69 colleges or universities that had players in the WNBA and counted how many of them are also listed in the 2006 US News \& World Report college rankings for the United States. The US News \& World Report college academic rankings are divided into three sections: 1) National Universities, which ranks the top 120 institutions (both Tier 1 and Tier 2 combined) according to academic strength. This particular ranking had 124 institutions because some institutions are tied for certain positions. For example, Princeton University and Harvard University are tied for the top spot; 2) Tier 3 institutions, which are a group of 64 colleges and universities listed alphabetically; and 3) Tier 4 institutions, which are a group of 60 institutions listed alphabetically. The total number of all institutions in the three groups is 248 .

Of the 69 colleges and universities that had players in the WNBA as of May 20, 2006, six (8.7\%) were not listed on any of the three rankings by US News \& World Report. A total of 64 institutions (25.8\% of all 248 institutions) with players in the
WNBA were listed on one of the three ranking lists. For the Top 120 academic institutions, a total of 46 institutions (37.1\%) with players in the WNBA were ranked; A total of 23 institutions (18.5\% of all top 124 institutions listed) were ranked in the top 60; a total of 8 institutions (6.4\% of all top 124 institutions listed) were ranked in the top 25; and 3 institutions (Harvard University, Duke University and Stanford University) (2.4\% of all top 124 institutions listed) were ranked in the top 5 (Table 12).

A total of 12 institutions (18.7\% of all 64 institutions ranked in Tier 3) with players in the WNBA were among the 64 institutions grouped in Tier 3. Finally, for the 60 institutions ranked in Tier 4, there were 6 institutions (10\% of all 60 institutions in Tier 4) among those 60 Tier 4 institutions in the US News \& World Report 2006 college rankings (Table 12).

Let us now examine the graduation rates of WNBA player.

For the 2006 WNBA roster, college or university attendance data were provided for 156 (89.1\%) of the 175 total players. College or university attendance data were not provided for 19 players. Out of the 156 players who attended colleges and universities in the US, data show that 155 (99.4\%) graduated or have at least a bachelor's degree. The 155 players with degrees comprised $88.6 \%$ of all 175 players in the WNBA.

A total of 113 Black players (72.9\% of all players with degrees) had bachelor's degrees. A total of 42 White players (27.1\% of all players with degrees) had a bachelor's degree. No college or university degree attainment data were available for one Black player who attended a university in the United States. Of the 114 Black players who attended institutions in the US, 113 (99.1\%) graduated or have bachelor's degrees. of the 42 White players who attended institutions in the US, 42 (100\%) graduated or have bachelor's degrees. The 113 Black players for whom data show that they have degrees, comprised $95.8 \%$ of all 118 Black players, and $64.6 \%$ of all players. The 42 White players for whom data show that they have degrees, comprised $73.7 \%$ of all 57 White players, and 24\% of all players (Table 13).

\section{Number of WNBA Players Sent By NCAA and NAIA Conferences}

Of the 32 National Collegiate Athletic Association (NCAA) Division I conferences 18 (56\%) had at least 1 player in the 2006 WNBA season. There is 1 player in the league from the

Table 11.

Institutions and regions sending players to the WNBA: 2006 season.

\begin{tabular}{|c|c|c|c|c|c|c|}
\hline $\mathbf{N}=175$ & & & & & & \\
\hline Region & Total $^{\#}$ Insts. Sent & $\%$ & Total $^{\#}$ of Black Players Sent & $\%$ of Blacks & Total $^{\#}$ of White Players Sent & $\%$ of Whites \\
\hline Northeast & 21 & 13.4 & 14 & 12.3 & 7 & 16.7 \\
\hline Midwest & 31 & 19.9 & 15 & 13.2 & 16 & 38.1 \\
\hline West & 19 & 12.2 & 11 & 9.6 & 8 & 19 \\
\hline Total & 156 & 100 & 114 & 100 & 42 & 100 \\
\hline
\end{tabular}

Source: Compiled and computed based on data on the WNBA website. ww.wnba.com, 2006. 
A. J. KABA

Table 12.

Total $^{\#}$ of players of each sending Institution to the WNBA, 2006 US News \& World Report academic ranking, 2006.

\begin{tabular}{|c|c|c|c|c|}
\hline $\mathrm{N}=156$ Players & \multirow{2}{*}{ Total $^{\#}$ of Players } & \multirow{2}{*}{ Rank $^{\#}$ of Top 120 Institutions } & \multirow{2}{*}{ Tier 3 Institutions } & \multirow{2}{*}{ Tier 4 Institutions } \\
\hline Institution & & & & \\
\hline University of Connecticut & 12 & 68 & & \\
\hline University of Tennessee, Knoxville & 11 & 85 & & \\
\hline University of Georgia & 8 & 58 & & \\
\hline Louisiana State University & 5 & & Tier 3 & \\
\hline Louisiana Tech University & 5 & & Tier 3 & \\
\hline Duke University & 4 & 5 & & \\
\hline Kansas State University & 4 & & Tier 3 & \\
\hline University of Florida & 4 & 50 & & \\
\hline University of Southern California & 4 & 30 & & \\
\hline Michigan State University & 3 & 74 & & \\
\hline Penn State University & 3 & 48 & & \\
\hline Rutgers University, New Brunswick & 3 & 60 & & \\
\hline Texas Tech University & 3 & & Tier 3 & \\
\hline University of Iowa & 3 & 60 & & \\
\hline University of Missouri, Columbia & 3 & 85 & & \\
\hline University of North Carolina, Chapel Hill & 3 & 27 & & \\
\hline University of Notre Dame & 3 & 18 & & \\
\hline University of Virginia & 3 & 23 & & \\
\hline Auburn University & 2 & 85 & & \\
\hline Baylor University & 2 & 78 & & \\
\hline Brigham Young University & 2 & 71 & & \\
\hline DePaul University & 2 & & Tier 3 & \\
\hline Florida International University & 2 & & & Tier 4 \\
\hline Florida State University & 2 & 109 & & \\
\hline Mississippi State University & 2 & & Tier 3 & \\
\hline North Carolina State University & 2 & 78 & & \\
\hline Old Dominion University & 2 & & & Tier 4 \\
\hline Purdue University & 2 & 60 & & \\
\hline Stanford University & 2 & 5 & & \\
\hline Tulane University & 2 & 43 & & \\
\hline University of California, Los Angeles & 2 & 25 & & \\
\hline University of Houston & 2 & & & Tier 4 \\
\hline University of Kansas & 2 & 97 & & \\
\hline University of Minnesota & 2 & 74 & & \\
\hline University of Oregon & 2 & 115 & & \\
\hline University of South Carolina, Columbia & 2 & 109 & & \\
\hline University of Texas, Austin & 2 & 52 & & \\
\hline University of Utah & 2 & 120 & & \\
\hline Vanderbilt University & 2 & 18 & & \\
\hline Boston College & 1 & 40 & & \\
\hline Colorado State University & 1 & 120 & & \\
\hline Florida Atlantic University & 1 & & & Tier 4 \\
\hline Georgetown University & 1 & 23 & & \\
\hline Georgia Institute of Technology & 1 & 37 & & \\
\hline Harvard University & 1 & 1 & & \\
\hline Iowa State University & 1 & 85 & & \\
\hline Liberty University & 1 & NA & & \\
\hline The Master's College & 1 & NA & & \\
\hline Ohio State University, Columbus & 1 & 60 & & \\
\hline Pepperdine University & 1 & 55 & & \\
\hline Saint Edwards University & 1 & NA & & \\
\hline S.E. Oklahoma State University & 1 & NA & & \\
\hline Temple University & 1 & & Tier 3 & \\
\hline Texas Christian University & 1 & 97 & & \\
\hline University of Alabama, Birmingham & 1 & & Tier 3 & \\
\hline University of Alabama, Tuscaloosa & 1 & 104 & & \\
\hline University of Arkansas, Fayetteville & 1 & & Tier 3 & \\
\hline University of California, Santa Barbara & 1 & 45 & & \\
\hline University of Central Florida & 1 & & Tier 3 & \\
\hline University of Cincinnati & 1 & & Tier 3 & \\
\hline University of Illinois, Champaign & 1 & 42 & & \\
\hline University of Memphis & 1 & & & Tier 4 \\
\hline University of Miami & 1 & 55 & & \\
\hline University of Nebraska, Lincoln & 1 & 97 & & \\
\hline University of Nevada, Las Vegas & 1 & & & Tier 4 \\
\hline University of Oklahoma & 1 & 109 & & \\
\hline University of Wisconsin & 1 & 34 & & \\
\hline Western Illinois University & 1 & na & & \\
\hline West Virginia University & 1 & & Tier 3 & \\
\hline
\end{tabular}




Total
NAIA = National Association of Intercollegiate Athletics
NCAA = National Collegiate Athletic Association
NA = Not Available
Source: “America's Best Colleges”, US News \& World Report College Rankings. http://www.usnews.com/usnews/edu/college/rankings/. Retrieved on May 20, 2006.

Source: “America’s Best Colleges”, US News \& World Report College Rankings. http://www.usnews.com/usnews/edu/college/rankings/. Retrieved on May 20, 2006.

Table 13.

College or university attendance and graduation rates of WNBA players: 2006 season.

\begin{tabular}{|c|c|c|c|c|c|c|c|}
\hline $\begin{array}{c}\mathrm{N}=175 \\
\text { Item }\end{array}$ & \# & $\begin{array}{l}\text { \% of Total } \\
\text { (N) }\end{array}$ & $\begin{array}{c}\text { As \% of Those } \\
\text { Enrolled }\end{array}$ & $\begin{array}{c}\text { \# }{ }^{\text {of }} \\
\text { Blacks }\end{array}$ & $\%$ & $\begin{array}{c}\text { \#of } \\
\text { Whites }\end{array}$ & $\%$ \\
\hline Total $^{\#}$ of all players enrolled in College/University in US & 156 & 89.1 & & & & & \\
\hline Total ${ }^{\#}$ of all players who graduated from College/University & 155 & 88.6 & 99.4 & 113 & 72.9 & 42 & 27.1 \\
\hline Total ${ }^{\#}$ of players without College Attendance Data Available & 19 & & & 4 & 21.1 & 15 & 78.9 \\
\hline \# of black players who attended but no year of graduation data Shown & 1 & & & & & & \\
\hline \# of white players who attended but no year of graduation data Shown & 0 & & & & & & \\
\hline$\%$ of black players who graduated within 118 black total (95.8\%) & & & & & & & \\
\hline$\%$ of white players who graduated within 57 white total (73.7\%) & & & & & & & \\
\hline$\%$ of black players who graduated within 114 blacks who attended (99.1\%) & & & & & & & \\
\hline$\%$ of white players who graduated within 42 whites who attended $(100 \%)$ & & & & & & & \\
\hline
\end{tabular}

Source: Compiled and computed based on data on the WNBA website. ww.wnba.com, 2006.

National Association of Intercollegiate Athletics (NAIA). There are 2 Division II conferences with 2 players combined in the league. A total of 6 NCAA Division I conferences had double figure numbers of players in the WNBA: Southeastern Conference, 38 players (24.4\% of all 156 players who attended institutions in the US); Big East Conference, 23 players (14.7\%); Big 12 Conference, 19 players (12.2\%); Atlantic Coast Conference, 17 players (10.9\%); Big Ten Conference, 16 players (10.3\%); Pacific-10 Conference, 10 players (6.4\%); Conference USA, 7 players (4.5\%); Mountain West Conference, 7 players (4.5\%); Western Athletic Conference, 5 players (3.2\%); Colonial Athletic Association, 2 players (1.3\%); Sun Belt Conference, 2 players (1.3\%); Atlantic 10 Conference, 1 player (0.6\%); Atlantic Sun Conference, 1 player (0.6\%); Big South Conference, 1 player (0.6\%); Big West Conference, 1 player (0.6\%); Ivy Group, 1 player (0.6\%); Mid Continent Conference, 1 player (0.6\%); West Coast Conference, 1 player (0.6\%) (Table 14).

The Golden State Athletic Conference of the National Collegiate Athletic Association (NAIA) had 1 player (0.6\%). Two Division II Conferences had 2 players: Heartland Conference, 1 player (0.6\%), and the Lone State Conference, 1 player $(0.6 \%)$ (Table 14).

\section{Number and Names of Institutions in States with Players in the WNBA: 2006 Season}

The 33 states (including Washington DC as a state equivalent) that had players in the WNBA on opening day on May 20, 2006, had 69 colleges and universities with each having at least 1 player in the league. According to Table 15, three states (9.1\% of all 33 states) have 6 different institutions with players in the WNBA: California, Florida and Texas. A total of 6 states (18.2\% of all 33 states) have 3 different institutions each with players in the WNBA: Alabama, Illinois, Louisiana, North Carolina, Tennessee and Virginia. A total of 9 states $(27.3 \%$ of all 33 states) have 2 different institutions each with players in the WNBA: Georgia, Indiana, Iowa, Kansas, Massachusetts,
Ohio, Oklahoma, Pennsylvania and Utah. Finally, a total of 15 states (45.4\% of all 33 sending states) had 1 institution each with players in the WNBA: Arkansas, Colorado, Connecticut, Michigan, Minnesota, Mississippi, Missouri, Nebraska, New Jersey, Nevada, Oregon, South Carolina, Washington DC, West Virginia, and Wisconsin (Table 15).

\section{International Players in the WNBA: 2006 Season}

The 2006 WNBA season had a substantial proportion of players from many countries across the world, including Australia, Belarus, Canada, Democratic Republic of Congo, the Czech Republic, Greece, Hungary, Ivory Coast, France, Latvia, Mali, Poland, Portugal, Russia, and Yugoslavia. For example, research by this author identified a total of 29 international players on rosters as of May 20, 2006 opening day of regular season games. These 29 players include both those who attended college in the US and those who came directly from abroad. The 29 international players comprised $16.6 \%$ of the total 175 players in the league. Among the 29 international players, White players accounted for 20 (69\%) and Black players account for 9 (31\%). The 20 White players comprised $35.1 \%$ of the total 57 White players. The 9 Black players comprised $7.6 \%$ of the total 118 Black players.

Also, the average age of all 29 international players is 26.3 years, and their average weight is 171.1 pounds. Their average height is 73.7 inches (almost 6'2'). The average age of the 20 White players is 26.7 years, and their average weight is 173.5 pounds. The average height of the 20 White international players is 73.9 inches (almost 6’2”). For the 9 Black international players, their average age is 25.7 years, and their average weight is 166.2 pounds. Their average height is 73.3 inches (just over 6'1”) (Compiled and computed based on 2006 data on the wnba.com).

In addition, a total of 19 international players arrived in the WNBA directly from overseas or abroad. of that total, 15 (78.9\%) are White and $4(21.1 \%)$ are Black. These 19 players 
Table 14.

Number of WNBA players sent by NCAA \& NAIA conferences.

\begin{tabular}{|c|c|c|}
\hline$N=156$ & & \\
\hline Name of Conference & $\begin{array}{l}\text { Number of } \\
\text { Players Sent }\end{array}$ & $\%$ \\
\hline American East Conference & 0 & 0 \\
\hline Atlantic 10 Conference & 1 & 0.6 \\
\hline Atlantic Coast Conference & 17 & 10.9 \\
\hline Atlantic Sun Conference & 1 & 0.6 \\
\hline Big 12 Conference & 19 & 12.2 \\
\hline Big East Conference & 23 & 14.7 \\
\hline Big Sky Conference & 0 & 0 \\
\hline Big South Conference & 1 & 0.6 \\
\hline Big Ten Conference & 16 & 10.3 \\
\hline Big West Conference & 1 & 0.6 \\
\hline Colonial Athletic Association & 2 & 1.3 \\
\hline Conference USA & 7 & 4.5 \\
\hline Division I Independents & 0 & 0 \\
\hline Horizon League & 0 & 0 \\
\hline Ivy Group & 1 & 0.6 \\
\hline Metro Atlantic Athletic Conference & 0 & 0 \\
\hline Mid Continent Conference & 1 & 0.6 \\
\hline Mid-American Conference & 0 & 0 \\
\hline Mid-Eastern Athletic Conference & 0 & 0 \\
\hline Missouri Valley Conference & 0 & 0 \\
\hline Mountain West Conference & 7 & 4.5 \\
\hline Northeast Conference & 0 & 0 \\
\hline Ohio Valley Conference & 0 & 0 \\
\hline Pacific-10 Conference & 10 & 6.4 \\
\hline Patriot League & 0 & 0 \\
\hline Southeastern Conference & 38 & 24.4 \\
\hline Southern Conference & 0 & 0 \\
\hline Southland Conference & 0 & 0 \\
\hline Southwestern Athletic Conference & 0 & 0 \\
\hline Sun Belt Conference & 2 & 1.3 \\
\hline West Coast Conference & 1 & 0.6 \\
\hline Western Athletic Conference & 5 & 3.2 \\
\hline $\begin{array}{l}\text { Heartland Conference (Division II, St. Edwards } \\
\text { University) }\end{array}$ & 1 & 0.6 \\
\hline $\begin{array}{l}\text { Lone Star Conference (Division II SE Oklahoma State } \\
\text { University) }\end{array}$ & 1 & 0.6 \\
\hline $\begin{array}{l}\text { Golden State Athletic Conference (NAIA), The } \\
\text { Master's College }\end{array}$ & 1 & 0.6 \\
\hline Total & 156 & 99.7 \\
\hline \multicolumn{3}{|l|}{$\begin{array}{l}\text { NAIA = National Association of Intercollegiate } \\
\text { Athletics }\end{array}$} \\
\hline NCAA = National Collegiate Athletic Association & & \\
\hline
\end{tabular}

Source: Compiled and computed based on data on the WNBA website. www.wnba.com, 2006.

comprised $10.9 \%$ of all 175 WNBA players (Table 16).
For comparative purposes, during the 2005-2006 NBA season, almost 1 out of every 5 of the 430 players (19\%) was from overseas. of the 82 international players, 56 were non-Black, 26 were Black (Kaba, 2011a: p. 4). International players were from 38 nations and territories, with 54 of them from 15 European countries, 11 from Latin American nations, 8 from Caribbean nations, 7 from sub-Saharan African nations, 3 from the Middle East, 2 from Canada, 2 from the Asian nation of Georgia, 1 each from Australia, China, South Korea and New Zealand (Kaba, 2011b).

\section{Discussion}

A contributing factor to the large number of Black WNBA players is that they comprise a substantial proportion of female college basketball players in the US, where the WNBA drafts the majority of its players. For example, according to a January 2005 NCAA report, in 2003-2004, there were an estimated 3947 (27\% of all female basketball players) non-Hispanic Black female basketball players and 9373 (64.2\% of all female basketball players) non-Hispanic White female basketball players in Divisions I, II \& III combined. These figures did not include non-resident alien female basketball players, who comprised 364 during that same period (“1999-2000-2003-2004 NCAA”, January 2005: pp. 5-9, 66). It is in Division I Women's college basketball (where the majority of WNBA players are either drafted or come from), however, that has a higher proportion of Black female players. For example, in 2003-2004, there were 1987 (41.6\% of all Division I female basketball players) non-Hispanic Black female Division I basketball players, and there were 2235 (46.8\% of all Division I female basketball players) non-Hispanic White female basketball players (“1999-2000-2003-2004 NCAA”, January 2005: p. 8, 67).

The reason why the proportion of Black female players is relatively high is that in October 2004, for example, there were 9,808,000 females enrolled in US colleges and universities, with non-Hispanic Black females comprising 1,525,000 (15.5\%), and White females in general accounted for 7,438,000 (75.8\%) ("School Enrollment”, 2005). To look at this differently, for example, as of March 2002, of the 282 million people in the US, males comprised 137.9 million (48.9\%), and females comprised 144.2 million (51\%). Non-Hispanic Black females comprised 19.3 million (13.4\% of the total female population) and non-Hispanic White females comprised 99.4 million (68.9\% of the total female population) ("The Black Population in the United States", 2003).

The data in this study also show that WNBA players, including Black players are highly educated, with at least a bachelor's degree. Among professional sports in 2006 in the United States, it appears as if WNBA players may have the highest proportion with at least a bachelor's degree, from America's colleges and universities, including from Harvard University. This is a trend also observed in society in general, with females now earning more bachelor's degrees than their male counterparts, despite experiencing exclusion from most colleges and universities in US history. Black females, who have experienced the most severe exclusion, have been the most impressive as the data above show and as new educational attainment data (from Bachelor's degree to professional and doctorate degrees) of the US show. By 2009, within the general US population Black females are behind only Asian males and Asian females (most of whom are foreign born) in the proportion within their 


\section{A. J. KABA}

Table 15.

Number \& names of institutions in states with players in the WNBA: 2006 season.

\begin{tabular}{|c|c|c|}
\hline $\mathbf{N}=69$ & & \\
\hline State & Total \# of Institutions & Names of Institutions \\
\hline Tennessee & 3 & University of Tennessee, University of Memphis, \& Vanderbilt University \\
\hline Texas & 6 & $\begin{array}{l}\text { University of Texas, Austin, Texas Christian, University of Houston, St. Edwards University, Texas Tech } \\
\text { University \& Baylor University }\end{array}$ \\
\hline Connecticut & 1 & University of Connecticut \\
\hline Louisiana & 3 & Louisiana State University, Louisiana Tech Uni, \& Tulane University \\
\hline California & 6 & $\begin{array}{l}\text { UCLA, USC, Pepperdine University, Stanford University, University of California, Santa Barbara, \& The } \\
\text { Master's College }\end{array}$ \\
\hline Florida & 6 & $\begin{array}{l}\text { Florida International, University of Florida, Florida Atlantic University, Florida State University, University of } \\
\text { Miami, \& University of Central Florida }\end{array}$ \\
\hline Georgia & 2 & University of Georgia \& Georgia Institute of Technology \\
\hline North Carolina & 3 & Duke University, N.C. State University, \& University of North Carolina \\
\hline Virginia & 3 & Liberty University, Old Dominion University, \& University of Virginia \\
\hline Kansas & 2 & Kansas State Uni \& University of Kansas \\
\hline Indiana & 2 & University of Notre Dame \& Purdue University \\
\hline Pennsylvania & 2 & Penn State University \& Temple University \\
\hline Illinois & 3 & DePaul Uni, University of Illinois, Champaign, \& Western Illinois University \\
\hline Alabama & 3 & Auburn University, University of Alabama, Birmingham, \& University of Alabama, Tuscaloosa \\
\hline Iowa & 2 & Iowa State University \& University of Iowa \\
\hline Utah & 2 & Brigham Young University \& University of Utah \\
\hline Michigan & 1 & Michigan State University \\
\hline Missouri & 1 & University of Missouri \\
\hline New Jersey & 1 & Rutgers University, State University of New Jersey, New Brunswick \\
\hline Massachusetts & 2 & Boston College \& Harvard University \\
\hline Minnesota & 1 & University of Minnesota \\
\hline Mississippi & 1 & Mississippi State University \\
\hline Ohio & 2 & Ohio State University \& University of Cincinnati \\
\hline Oklahoma & 2 & Southeastern Oklahoma State University \& University of Oklahoma \\
\hline Oregon & 1 & University of Oregon \\
\hline South Carolina & 1 & University of South Carolina, Columbia \\
\hline Arkansas & 1 & University of Arkansas, Fayetteville \\
\hline Colorado & 1 & Colorado State University \\
\hline Nebraska & 1 & University of Nebraska \\
\hline Nevada & 1 & University of Nevada, Las Vegas \\
\hline Washington DC & 1 & Georgetown University \\
\hline West Virginia & 1 & University of West Virginia \\
\hline Wisconsin & 1 & University of Wisconsin \\
\hline Total & 69 & \\
\hline
\end{tabular}

Source: Compiled and computed based on data on the WNBA website. www.wnba.com, 2006.

group or category enrolled in college. The dedication to educational attainment of Black American females is so strong that they would go deep into debt to attain their college education (Fiegener, 2009; Hoffer et al., 2003; Kaba, 2005, 2011c). For example, due to Black females, among those in the United States who earned doctorates in 2008, Blacks had the highest level of debt: \$38,586; \$29,698 for American Indians; \$27,553 for Hispanics; \$25,761 for multiracial individuals; \$21,299 for
Whites; and \$13,216 for Asians (Fiegener, 2009: p. 53).

In addition to their love for the game of basketball, Black females in particular and females in general use the game to win scholarships to earn their bachelor's or master's degrees, which can cost tens of thousands of dollars or more. Videon (2002) points out that: “...participation in athletics is associated with an array of positive educational outcomes. Students who participate in sports have better attendance records, lower rates 
Table 16.

Players coming directly from overseas to the WNBA.

\begin{tabular}{ccccr}
$\begin{array}{c}\text { Total } \\
\text { from Overseas }\end{array}$ & $\begin{array}{c}\text { Total }^{\#} \text { from Overseas } \\
\text { Black Players }\end{array}$ & $\%$ & $\begin{array}{c}\text { Total }^{\#} \text { from Overseas } \\
\text { White Players }\end{array}$ & $\%$ \\
\hline 19 & 4 & 21.1 & 15 & 78.9 \\
\hline
\end{tabular}

Source: Compiled and computed based on data on the WNBA website. www. wnba.com, 2006.

of discipline referrals, and higher academic self-esteem and are more likely to be in a college preparatory curriculum, earn higher grades, and aspire to, enroll in, and graduate from college” (p. 415). According to Lapchick (2011), during the 2011 NCAA Men's and Women's tournaments: “95 percent (60) of the women's teams compared to 63 percent (42) of the men's teams graduated at least 60 percent of their players" (p. 1; also see Gaston-Gayles, 2004: p. 75). Hamilton (2003) writes of a talented African American University of Tennessee women's basketball player named Kara Lawson, who despite being one of the top college basketball players in the country, managed to graduate “.... as a finance major with 3.75 GPA” (p. 22).

According to Kaba's (2011a) study of the 2005-2006 NBA season, data were only provided for the academic institutions (high schools, colleges and universities) in the US that the players attended, but not whether they graduated. There were 35 players who entered the league directly from US high schools during that season (also see Kaba, 2011b).

Finally, it is important to briefly discuss why society would allow WNBA players to be paid a salary of $\$ 50,000$ by 2006 while their brothers or male counterparts are paid an average of almost \$4 million during the $2005-2006$ season. This is the case even with advertisement or endorsement opportunities. Fans appear to be willing to pay the males substantially more than their female counterparts. As a result, a substantial number of WNBA players have to go overseas to play professionally once the WNBA season ends because they are paid better in those nations than in the United States (James, 2002; McCabe, 2011; Spencer \& McClung, 2001; Staffo, 1998ab; Ruihley et al., 2010; Wearden \& Creedon, 2002). Staffo (1998a) notes that an estimated 500 women from the United States were playing overseas (p. 190). Staffo (1998a) also adds that: "Professional leagues outside the United States existed in Spain, Italy, Germany, Scandinavia and Japan. A few US stars, such as Teresa Edwards and Katrina McClain, made an estimated \$200,000 for a six-month season” (p. 190).

Even though some WNBA players earn significantly more than the average and that some also get endorsements, those figures are not as high as the males. Issacson (2006) points out that: "The highest-paid WNBA players earn about $\$ 90,000$, and with endorsement deals, stars can push that to as much as $\$ 200,000$. Overseas salaries for the best players approach $\$ 500,000$ ” (p. 1). Staffo (1998a) also notes that “...superstars like Lisa Leslie, Rebecca Lobo and Sheryl Swoopes are said to be making up to $\$ 250,000$ when promotional fees are added in...” (p. 193). According to Spencer and McClung (2001), former WNBA star Cynthia Cooper signed endorsement contracts with both General Motors and Nike for an estimated $\$ 500,000$ annually (p. 334). Ruihley et al. (2010) note that NBA player LeBron James, who entered the league directly from high school, signed a multi-year contract with Nike for
$\$ 90$ million; that in 2009, golf player Tiger Woods' endorsement income was $\$ 110$ million; and that in 1997 former NBA player Michael Jordan earned $\$ 40$ in endorsements (pp. 133-135).

Fans tend to show more support for male sports through their rate or level of attendance and also through ticket price. According to McCabe (2011), “A critical outcome of understanding the nature of spectators' involvement with competitive sports is its relevance in predicting consumption attitudes and purchasing behavior” (pp. 107-108). Smith and Roy (2011) claim that: "Ticket sales represent the most important source of local revenues for most sport teams. Revenue from ticket sales makes up at least $50 \%$ of all local revenues for the four major professional sports leagues in the United States (NFL, MLB, NBA, and NHL)” (p. 93). According to Staffo (1998a): "During the first [WNBA] season average attendance was 9669 per game, with the single largest crowd being 18,937 when Houston played at Charlotte August 16, 1997... The first championship game was played August 30 at The Summit, with the Houston Comets defeating the New York Liberty. Attendance was 16,285” (p. 192). Cotes and Humphreys (2007) point out that the average attendance to NBA games from 1991 to 2001 was 16,671 (p. 167).

Jacobsen (2010) reports that in the WNBA: “[Ticket prices for] Most franchises start around $\$ 10$ and go as high as $\$ 200$ or more. Single-game tickets to the defending champ Phoenix Mercury begin at $\$ 10$ and go as high as $\$ 195.25$. The New York Liberty charges anywhere from $\$ 10$ to $\$ 260$, the latter for courtside seats” (p. B1). It is noted that the average NBA ticket price in 2010 was \$48.08; \$99.25 for the Los Angeles Lakers; and \$88.66 for the New York Knicks ("NBA Sees Ticket Prices Slump,” 2010: p. C2). Staffo (1998b) claims that during the 1996-1997 NBA season, the price of front row seat at a New York Knicks home game at the Madison Square Garden was $\$ 1000$ (p. 15). Voisin (2011) points out that the NBA's annual revenue is $\$ 4$ billion.

How can one explain this human behavior of gender bias in sports? According to James (2002): "It has been proposed that women's sports have a different appeal than men's sports” (p. 141). Wearden and Creedon (2002) claim that: "Feminist scholars point to the huge disparity in endorsement revenue between male and female athletes as evidence of a male hierarchy in sport... The gender hierarchy argument holds that female athletes are both "other than" and "less than" their male counterparts” (p. 189).

In addition, females involved in team sports may experience more discrimination in earnings than those in individual sports. For example, according to Wearden and Creedon (2002): “... researchers have found a sex-appropriate ranking scheme in sport that suggests individual sports (that is tennis, figure skating, golf and gymnastics) are more appropriate for women than team sports" (p. 189). Staffo (1998a) attempts to present this philosophical explanation of gender bias in sports: "Finally one big difference between the development of men's sports and women's sports in the US is that women's sports have always been based in the philosophy and are an outgrowth of the women's physical education program and therefore have generally maintained a purer attitude in the pursuit of sports for sports sake. This philosophy has generally kept women's sports free from the corruption that has frequently marred men's sports” (p. 195). 


\section{Conclusion}

This study has attempted to present an in-depth examination of the players in the 2006 United States Women's National Basketball Association (WNBA) season. The data show that Black players or players of African descent comprised the majority of the league as of the first day of the 2006 season. Almost all of the players who attended colleges and universities in the United States graduated. These athletes also attended many of the most selective institutions in the United States, including Harvard University. Colleges and universities from the Southern United States sent the majority of all players to the WNBA in 2006. International players comprised a significant proportion of players in the WNBA in 2006. WNBA players, like professional women athletes in other sports do not get a fair compensation for their talents due to gender bias within the society.

However, the data in this study also indicate that these women are set to take-up various leadership positions after their athletic careers not only in the United States, but the world as well. They have the first class academic education and discipline from sports that they will take with them in their future leadership roles. Finally, these players also have become representatives or ambassadors of the colleges and universities and states where they were educated.

\section{REFERENCES}

Abney, R. (1999). African American women in sport. Journal of Physical Education, Recreation \& Dance, 70, 35-38.

America's Best Colleges (2006). US News \& World Report. URL (last checked 20 May 2006) http://www.usnews.com/usnews/edu/college/rankings

Baker, C. A. (2008). Why she plays: The world of women's basketball. Winnipeg: Bison Books.

US Census Bureau (2003). The black population in the United States: March 2002. Washington DC: Government Printing Office.

Cahppell, R. H., \& Karageorghis, C. I. (2001). Race, ethnicity, and gender in British basketball. Women in Sport \& Physical Activity Journal, 10, 29-46.

Coates, D., \& Humphreys, B. R. (2007). Ticket prices, concessions and attendance at professional sporting events. International Journal of Sports Finance, 2, 161-170.

Gaston-Gayles, J. L. (2004). Examining academic and athletic motivation among student athletes at a Division I University. Journal of College Student Development, 45, 75-83. doi:10.1353/csd.2004.0005

Gomez, M. A., Lorenzo, A., Ortega, E., Sampaio, J., \& Ibanez, S. J. (2009). Game related statistics discriminating between starters and nonstarters players in Women's National Basketball Association League (WNBA). Journal of Sports Science and Medicine, 8, 278-283.

Grundy, P., \& Shackelford, S. (2007). Shattering the glass: The remarkable history of women's basketball. Chapel Hill, NC: The University of North Carolina Press.

Fiegener, M. K. (2009). Doctorate recipients from US universities: Summary Report 2007-2008. Directorate for social, behavioral, and economic sciences, National Science Foundation. Table 24, 53. Arlington: Division of Science Resources Statistics.

Hoffer, T. B., Sederstrom, S., Selfa, L., Welch, V., Hess, M., Brown, S., Reyes, S., Webber, K., \& Guzman-Barron, I. (2003). Doctorate recipients from United States universities: Summary Report 2002 (pp. 113-115). Chicago: National Opinion Research Center.

Hamilton, K. (2003). Courting success; University of Tennessee finance major balances hoops excellence with academic achievement. Black Issues in Higher Education, 20, 22-23.

Isaacson, M. (2006). Promotions in motion: WNBA athletes do more than play: They also sell the league. Knight Ridder Tribune Business News, 1.

Jacobsen, L. (2010). Shock is pleased by ticket sales for opener. Tulsa World, B1.

James, J. D. (2002). Women's and men's basketball: A comparison of sport consumption motivations. Women in Sport \& Physical Activity Journal, 11, 141-170.

Kaba, A. J. (2011a). African Americans in the National Basketball Association (NBA), 2005-2006: Demography and earnings. International Journal of Social and Management Sciences, 4, 1-25.

Kaba, A. J. (2011b). Characteristics of players in the 2005-2006 US National Basketball Association (NBA). URL (last checked 14 October 2011).

http://www.hollerafrica.com/index.php

Kaba, A. J. (2011c). Black American females as geniuses. Journal of African American Studies, 15, 120-124. doi:10.1007/s12111-010-9134-1

Kaba, A. J. (2006a). The blood and family relations between Africans and Europeans in the United States. African Renaissance, 3, 105114.

Kaba, A. J. (2006b). Race, geography and territorial inheritance: People of Black African, European and Chinese Descent. URL (last checked 14 October 2011).

http://www.hollerafrica.com/

Kaba, A. J. (2005). Progress of African Americans in higher education attainment: The widening gender gap and its current and future implications. Education Policy Analysis Archives, 13, 1-34.

Kochman, L., \& Goodwin, R. (2003). Market efficiency and the women's NBA. American Business Review, 21, 141-143.

Lapchick, R. (2011). Keeping score when it counts: Academic progress/graduation success rate study of NCAA Division I Women's and Men's Basketball Tournament Teams. URL (last checked 20 October 2011)

http://tidesport.org/Grad\%20Rates/2011_Womens_Bball_Study_FIN AL.pdf

Lapchick, R., \& Kushner, D. (2006). The 2005 racial and gender report card: Women's National Basketball Association. Orlando: University of Central Florida.

McCabe, C. (2011). Spectators' relationship women's professional basketball: Is it more than sex? North American Journal of Psychology, $13,107-122$.

McDonald, M. (2000). The marketing of the Women's National Basketball Association and the making of Post-Feminism. International Review for the Sociology of Sports, 35, 35-47. doi:10.1177/101269000035001003

NBA Sees Ticket Prices Slump (2010). The Times-Transcript. Moncton, C2.

Ogden, C. L., Fryar, C. D., Carroll, M. D., \& Flegal, K. M. (2004). Mean body weight, height, and body mass index, United States 1960-2002. Advance data from vital and health statistics; no 347. Hyattsville, MA: National Center for Health Statistics.

Picker, D. (2006). East all-stars break through on night for young and old. New York Times, D.6.

US Census Bureau (2005). School enrollment-Social and economic characteristics of students: October 2004. Washington DC: Government Printing office.

Smith, J. G., \& Roy, D. P. (2011). A framework for developing customer orientation in ticket sales organizations. Sports Marketing Quarterly, 20, 93-102.

Spencer, N. E., \& McClung, L. R. (2001). Women and sport in the 1990s: Reflections on embracing stars, ignoring players. Journal of Sport Management, 15, 318-349.

Ruihley, B., Runyan, R. C., \& Lear, K. E. (2010). The use of sport celebrities in advertising: Replication and extension. Sport Marketing Quarterly, 19, 132-142.

Staffo, D. (1998a). The history of women's professional basketball in the United States with an emphasis on the Old WBL and the New 


\section{A. J. KABA}

ABL and WNBA. Physical Educator, 55, 187-198.

Staffo, D. F. (1998b). The development of professional basketball in the United States, with an emphasis on the history of the NBA to its 50th anniversary season in 1996-1997. Physical Educator, 55, 9-18.

Videon, T. M. (2002). Who plays and who benefits: Gender, interscholastic athletics, and academic outcomes. Sociological Perspectives, 45, 415444. doi:10.1525/sop.2002.45.4.415

Voisin, A. (2011). NBA must fix its broken business model. The Sacramento Bee. URL (last checked 8 October 2011).

http://m.standard.net/topics/sports/2011/07/01/voisin-nba-must-fix-br oken-business-model

Wearden, S., \& Creedon, P. J. (2002). "We Got Next": Images of women in television commercials during the inaugural WNBA Season. Culture, Sport, Society, 5, 189-210. doi:10.1080/713999865

Yafie, R. C. (1997). The WNBA's full court press. The Journal of Business Strategy, 18, 32-33.

1999-00-2003-04 NCAA Student-Athlete Ethnicity Report (2005). Published by the National Collegiate Athletic Association. P.O. Box 6222. 317/917-6222. www.ncaa.org. 